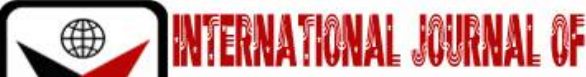

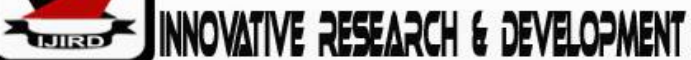

ISSN 2278-0211 (Online)

\section{Efficiency of Poultry Egg Farmers in Ondo State, Nigeria}

\author{
Oluyemi Busayo Olushola \\ Lecturer, Department of Agricultural Resource Economics, \\ Federal University Of Technology Akure, Ondo State, Nigeria \\ Falaye Motunrayo Helen \\ Lecturer, Department of Economics and Management Studies, \\ Afe Babalola University, Ado Ekiti, Nigeria
}

\begin{abstract}
:
This study estimated the efficiency of Poultry-egg Farmers in Ondo State. The specific objectives were to estimate the technical, allocative and economic efficiency of egg production, profitability by scale of operation, identify factors affecting the efficiency of the farmers and examine the constraints they faced. The study adopted the multistage sampling procedure. Data were collected from 120 respondents through a structured questionnaire. Descriptive statistics, Gross margin, Cobb Douglas Stochastic Frontier production function and inefficiency effect model were used to analyze the data. The findings showed that $81.7 \%$ of the farmers were male and the mean age was 46.2. Most of the respondents constituting about $90.4 \%$ were married and majority (84.3\%) had tertiary education. $68.7 \%$ of the respondents had access to credit facility. The profitability analysis showed that feed constituted the highest variable cost item. Small scale enterprise spent $83.80 \%$ on feed, medium scale spent $85.18 \%$ while large scale incurred $76.41 \%$ on feed. The technical efficiency result showed that $40.9 \%$ of the respondents were most efficient. The mean technical efficiency of the farmers was $83.1 \%$ while the minimum and maximum efficiencies were $13 \%$ and $97 \%$ respectively. About 3.5\% of the respondents were below 50\% economic efficiency and the mean economic efficiency was 0.771 . The allocative efficiency analysis revealed that farmers were at least 50\% efficient and the mean allocative efficiency was 0.948. Inefficiency result showed that feed and stock had significant influence on egg production at ( $p=0.1$ ). None of the identified socio-economic variables had significant influence on egg production. High cost of input was rated the major constraint and inadequate storage facilities was rated as the least constraint.
\end{abstract}

Keywords: Efficiency, Poultry-egg farmers, gross margin, Cobb Douglas, stochastic frontier production

\section{Introduction}

The importance of livestock industry cannot be overemphasized in the Nigerian economy because it provides animal protein such as meat, egg and milk. According to FAO (2010) the minimum intake of protein for an average person should be $65 \mathrm{~g}$ per day and $36 \mathrm{~g}$ of this should be animal protein that is, from animal sources. This is not the case in the country because it is presently unable to meet this requirement. The animal protein consumption in Nigeria is $15 \mathrm{~g}$ per person per day (Tijani et al., 2012) and which is a wide gap from FAO's recommendation. This has successfully resulted in hunger, nutrition poverty and stunted growth as well as increase in spread of diseases in the country. The sources of animal protein include fish, egg, poultry meat, beef, milk, beacon, pork, and mutton and they are mostly not affordable. Some of the regular sources of animal protein in Nigeria are local chicken, beef and frozen chicken.

Poultry farming is the art of raising chickens, turkeys, ducks and geese for the purpose of using their meat and eggs for food. In Nigeria, so many farmers are into poultry production but the level of technology application still remains low which often result in low productivity. Various studies (Tijjani et al., 2012; Nurudeen, 2012; FA0, 2010; Yusuf and Malomo, 2007; Ojo, 2003) concluded that commercializing the production of meat and eggs derived from prolific animals like poultry birds is very important and necessary to meet animal protein requirements from domestic sources. Poultry production offer considerable potential for bridging the nutritional gap in view of the fact that high yielding exotic poultry are easily adaptable to our environment and the technology of production is relatively simple with returns on investment very high.

Poultry production is a commercially viable business that demands the application of the knowledge of farm management. Olukosi and Ogungbile (1989) analyzed the profitability of poultry enterprises with a view to generating the research outputs for guiding the farmers in the right and adequate use of resources/combination to maximize profit and encourage potential entrants of public and private sector to increase output and bridge the gap between national demand and supply of animal protein. 
Intensive method of rearing the birds is common in the urban centre while the semi-intensive and the extensive method are carried out in the rural areas. Akpabio et al. (2007) described the poultry industry as the fastest means of bridging the protein gap prevailing in Nigeria. The rational for the promotion of poultry production is predicated on the fact that poultry meat and egg offer considerable potentials for meeting human need for dietary animal supply (Folorunsho and Onibi, 2005). According to Ukoha and Augustine (2007), poultry industry goes a long way in providing animal protein for the populace because it provides meat and egg in very short time. The poultry as an industry is diversified with different types of business interest such as egg production, broiler production, hatchery and poultry equipment business interest (Amos, 2006).

Egg production entails using good layer breeds. The eggs are sold off fresh to the public and when the layers are too old to lay or are no longer laying eggs regularly as usual, they are Culled off from the farm. Laying hens in egg producing farms are usually of small body frame and body weight compared to broilers and other birds. They can be classified into two groups: dual purpose chickens or egg producing chickens. These egg producing chicken breeds have been bred and raised purposely for optimum egg production (to lay up to 300 eggs per year) rather than high meat yield (Beutler, 2007). Dual purpose chickens are smaller in size than commercial meat breeds. They are used for meat as well as egg production, and can produce around 200 to 250 eggs per year (FAO, 2010).

\section{Methodology}

Primary data we be used for this study. The primary data will be collected with a set of structured questionnaire that was be administered to selected poultry egg producers in the study area. This will be used to obtain information on the socio-economic characteristics, profitability and efficiencies of the farmers

A multi-stage sampling procedure will be used for the study. The first stage will involve the use of purposive sampling technique to select two Local Government Areas (LGAs) namely Akure South LGA and Akure North LGA, while the second stage will involve a random selection of three communities from each of the two LGAs. The third stage will involve the selection of twenty (20) poultry egg farmers in each community making a total of one hundred and twenty (120) poultry egg farmers in the study area.

\section{Method of Data Analysis}

\subsection{Descriptive Statistics}

Descriptive statistics such as mean, standard deviation, frequency distribution and percentages will be used to analyze the socio-economic characteristics and constraints that are faced by the poultry farmers. The mean and the standard deviation will be derived using the following formulae;

$\operatorname{Mean}(\overline{\mathrm{X}})=\sum \frac{X}{N}$

and

Standard deviation $=\sqrt{\frac{1}{\mathrm{~N}} \sum_{\mathrm{i}=1}^{\mathrm{N}}\left(\mathrm{x}_{1}-\mu\right)^{2}}$

Where $\mathrm{X}=$ the variable under consideration, e.g. age of farmers

$\mathrm{N}=$ number of farmers

$\mu=$ sample mean

\subsection{Profitability Analysis}

Gross margin analysis will be used to determine the cost and returns from the poultry egg farmers and the Net Farm Income will also be estimated. According to Olukosi and Erhabor (1988), Net Farm Income (NFI) is the difference between the Gross Income (GI) and total cost of production. It measures the strength and weakness of the farm. This will be used to estimate the gross margin and the net income accruing to the poultry layers producers in the study area. The model for estimating the NFI is represented by the following equation.

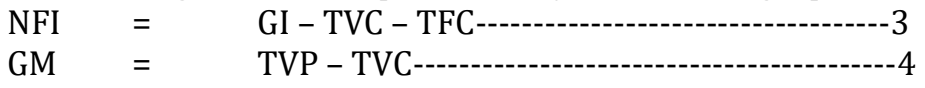

Where;

$\begin{array}{lll}\text { NFI } & = & \text { Net Farm Income (Naira) } \\ \text { GI } & = & \text { Gross Income (Naira) } \\ \text { TVC } & = & \text { Total Variable Cost (Naira) } \\ \text { TFC } & = & \text { Total Fixed Cost (Naira) } \\ \text { TVP } & = & \text { Total Value of Production }\end{array}$

Total Variable Cost: These costs vary with output. They include feed, stock, labour, drug, vaccination, transportation, water, electricity and so on.

- Total Fixed Cost: They are costs that do not vary with the levels of output in the short run (Olukosi and Erabor, 1988).This includes expenses on land, equipments, building, machinery amongst others.

\subsection{Stochastic Production Frontier}

The Cobb-Douglas stochastic frontier production function will be used for this study to estimate the technical efficiency of the poultry egg farmers. It has been widely used in agricultural studies and because of its mathematical simplicity. It is specified as: 
$\operatorname{InY}=\beta 0+\beta \operatorname{InX} 1+\beta 2 \operatorname{InX} 2+\beta 3 \operatorname{InX} 3+\beta 4 \operatorname{InX} 4+\beta 5 \operatorname{InX} 5+\beta 6 \operatorname{InX} 6+(\mathrm{Vi}-\mathrm{Ui})$

Where:

$\mathrm{Y}=$ Value of poultry outputs (value for eggs and spent/culled layers) (Naira)

$\mathrm{X} 1$ = Farm size (number of birds)

$\mathrm{X} 2$ = vaccine (Naira)

$\mathrm{X} 3=$ Feed (Naira)

$\mathrm{X} 4$ = Labour (Naira)

X5 = Drugs (Naira )

X6 = Utilities and other expenses (Naira)

$\beta I-\beta 6=$ coefficients of parameters estimated.

$\beta 0=$ intercept.

$\mathrm{Vi}=$ random or statistical disturbance term which captures the effect of weather and other factors outside the control of the farmer.

$\mathrm{Ui}=$ farmer and farm specific characteristics related to production efficiency (technical inefficiency effects).

\subsection{Inefficiency Model}

Technical inefficiency effect is as a result of behavioral factors which could be controlled by efficient management. This model will be used to analyze the factors affecting the technical efficiency of the farmers. (Battase and Corra,1997). The model is specified as;

$\mathrm{Uij}=\delta 0+\delta 1 \mathrm{Z} 1+\delta 2 \mathrm{Z} 2+\delta 3 \mathrm{Z} 3+\delta 4 \mathrm{Z} 4+\delta 5 \mathrm{Z} 5+\delta 6 \mathrm{Z} 6+\delta 7 \mathrm{Z} 7+\delta 8 \mathrm{Z} 8$

Where:

Uij = technical inefficiency of the ith farmer and jth observation of the farmer.

$\delta 0=$ constant

$\delta s$ = parameters to be estimated

$\mathrm{Z1}$ = Age (years)

$\mathrm{Z2}$ = Education (years)

$\mathrm{Z3}$ = farming experience (years)

$\mathrm{Z} 4$ = cooperative society (yes $=1$, otherwise $=0$ )

$\mathrm{Z} 5$ = access to credit (yes $=1$, otherwise $=0$ )

$\mathrm{Z6}=$ gender $($ male $=1$, female $=0)$

$\mathrm{Z7}=$ marital status $($ married $=1$, single $=2$, divorced $=3$, widowed $=4$ )

$\mathrm{Z8}$ =household size (in numbers)

\section{Results and Discussion}

\subsection{Socio-economic Characteristics of Poultry-Egg Farmers}

Out of 120 farmers used for the study, only 115 of them provided usable data for the analysis. The results for the socio-economic characteristics are presented below;

The age distribution of the respondents shows that about $96.5 \%$ of the poultry farmers were at most or less than 60 years of age and with a mean age of 46.18. This implies that majority of the poultry egg farmers were in their economically active and productive ages. It also means poultry egg production was embarked on by farmers who were physically and mentally fit to face challenges. The study agrees with Anwasia (2015) whose findings revealed that 69\% 0f broiler farmers fell within the productive age range. Hence, the farmers being in their economically active and productive ages suggest high level of vitality for agricultural activities and production.

The distribution of the farmers according to gender revealed that $81.7 \%$ were males while $18.3 \%$ were females. This shows that the enterprise is dominated by male and this is expected because of the energy demanding nature of the poultry enterprise. The result goes in line with the study of Umar (2012) which stated that 66\% of his respondents were male while the remaining 34\% were female, he explained also that it could be due to the drudgery nature, physical and energy demands of the enterprise.

The marital status of the respondents shows that $90.4 \%$ are married, $7.0 \%$ are single, while $1.7 \%$ is widowed. This is in accordance with the findings of Ajala et al (2007) that revealed that $86 \%$ are married and $14 \%$ are single. This implies that majority of the respondents are responsible and also, the high number of married people in the business may lead to reduced labour cost as the children can substitute for labour in poultry production.

As shown below $84.3 \%$ of the population attended tertiary institutions and $11.3 \%$ attended secondary institution while $4.3 \%$ attended only primary institution therefore, it can be deduced that majority of the farmers in the enterprise are educated. In management of poultry enterprise, education is important. The educational level of the farmers would make them understand and practice modern farm methods thereby increasing productivity and profitability. This goes with Umar (2012) which indicated a high literacy level of 99\% among poultry egg farmers in Bauchi State.

The distribution of respondents according to their household size. Majority of the respondents (61.7\%) fell within the household size of 5 to 10 persons while the remaining 38.3\% had below 5 persons and the mean household size was 5 persons per household the study agrees with the findings of Nwaru (2004) who reported that large household size enhance family labour availability since it reduces labour constraints in poultry egg production. it also goes in line with the study of Umar (2012) who stated that 72\% of his respondents have household size at most 10 persons. 
According to the result $15.7 \%$ has less than 5 years poultry farming experience, majority of the farmers (47\%) has between 5 and 10 years farming experience, $16.2 \%$ had between 11 and 15 years of experience, $10.4 \%$ had between 16 to 20 years of experience while $9.6 \%$ had more than 20 years of experience. this is in accordance with the study of Umar (2012) who stated that majority of the farmers have experience between 6 and 10 years making 58\% of the population. This study also agrees with that of Anwasia (2015) who stated that 52\% of the farmers have between 6 to 10 years experience while $34 \%$ has experience of 1 to 5years. It can be said that most of the farmers have been into poultry farming for at least 5 years in the study area. This suggests that majority of the farmers are new entrants in the industry. It is expected that productivity increases with years of experience and it increases the knowledge of adequate input combination.

Access to credit of the respondents is represented in Table 7. 68.7\% of the farmers have access to credit while the remaining 31.3\% does not have access to credit. This indicates that a quite large amount of the farmers have access to one type of credit or the other. Access to credit is believed to increase the productivity of the respondent according to the Ukoha et al (2007).

The distribution of the respondents according to their sources of credit is revealed that Majority of the respondents that have access to credit which constituted $39.2 \%$ sourced it from Cooperative societies, followed by $18.9 \%$ which got their credit from Commercial Banks, 10.1\% got theirs from Bank of Industry while 11.3\% got loans from Bank of Agriculture. This shows that Cooperative Society may be an easier institution to access credit because of its relatively low interest rates.

\begin{tabular}{|c|c|c|}
\hline Variable & Frequency & Percentage (\%) \\
\hline \multicolumn{3}{|l|}{ AGE } \\
\hline $30-40$ & 31 & 27.0 \\
\hline $41-50$ & 52 & 45.2 \\
\hline $51-60$ & 28 & 24.3 \\
\hline$>60$ & 4 & 3.5 \\
\hline TOTAL & 115 & 100 \\
\hline \multicolumn{3}{|l|}{ GENDER } \\
\hline Male & 94 & 81.7 \\
\hline Female & 21 & 18.3 \\
\hline Total & 115 & 100 \\
\hline \multicolumn{3}{|l|}{ Marital status } \\
\hline Married & 104 & 90.4 \\
\hline Single & 8 & 7.0 \\
\hline Widowed & 2 & 1.7 \\
\hline Divorced & 1 & 0.9 \\
\hline Total & 115 & 100 \\
\hline \multicolumn{3}{|l|}{ Level of Education } \\
\hline Tertiary & 97 & 84.3 \\
\hline Secondary & 13 & 11.3 \\
\hline Primary & 5 & 4.3 \\
\hline Total & 115 & 100 \\
\hline \multicolumn{3}{|l|}{ Household size } \\
\hline$<5$ & 44 & 38.3 \\
\hline $5-10$ & 71 & 61.7 \\
\hline Total & 115 & 100 \\
\hline \multicolumn{3}{|l|}{ Farming experience } \\
\hline$<5$ & 18 & 15.7 \\
\hline $5-10$ & 54 & 47.0 \\
\hline $11-15$ & 20 & 17.4 \\
\hline $16-20$ & 12 & 10.4 \\
\hline$>20$ & 11 & 9.6 \\
\hline Total & 115 & 100 \\
\hline \multicolumn{3}{|l|}{ Access to credit } \\
\hline Yes & 79 & 68.7 \\
\hline No & 36 & 31.3 \\
\hline Total & 115 & 100 \\
\hline \multicolumn{3}{|l|}{ Source of credit } \\
\hline Commercial bank & 15 & 18.9 \\
\hline Bank of Industry & 8 & 10.1 \\
\hline Bank of Agriculture & 9 & 11.3 \\
\hline Cooperative society & 31 & 39.2 \\
\hline Money lenders & 8 & 10.1 \\
\hline Family and friends & 6 & 7.6 \\
\hline Micro-finance & 2 & 2.5 \\
\hline Total & 79 & 100 \\
\hline
\end{tabular}

Table 1: Socio-economic Characteristics of Poultry-Egg Farmers 


\subsection{Scale of Production}

The scale of production of the farmers is presented in Table 2 . Almost $65 \%$ of the farmers were small scale farmers while about $34 \%$ were medium scale and a little less than $2 \%$ were large scale. This revealed that the layers poultry farmers in the study area were largely small scale farmers. Many of them may have reduced their scale of production as a result of increase in the cost of production especially in poultry feeds. Umar (2012) also confirmed by stating that 53\% of his respondents which constituted the majority of his respondents have less than 1000 birds which means their scale of enterprise is small, 31\% kept between 1000 and 4999 birds while $16 \%$ kept more than 5000 which is large scale enterprise.

\begin{tabular}{|l|c|c|}
\hline Scale & Frequency & Percentage \\
\hline Small Scale $(30-999)$ & 74 & 64.35 \\
Medium Scale $(1,000-4,999)$ & 39 & 33.91 \\
Large Scale $(\geq 5,000)$ & 2 & 1.74 \\
Total & 115 & 100.0 \\
\hline
\end{tabular}

Table 2: Scale of Production Based on Stock Size

Source: field survey: 2017

(Mean Stock Size $=969.22$ birds Std. Deviation $=1043.55$ birds

\subsection{Profitability of Poultry-Egg Enterprise in the Study Area}

\subsubsection{Depreciation Schedule for Fixed Cost}

Table 3 shows the depreciation schedule of the fixed cost of the scales of poultry enterprise. The mean total cost of the small-scale enterprise was $\mathrm{N} 787,854.44$ and it had a total depreciation of $\mathrm{N} 55,193.29$, the medium scale enterprise has mean total cost $\mathrm{N} 312,430.83$ and depreciation of $\mathrm{N} 109,337.46$ and the large scale had $\mathrm{N} 7,536,000.00$ with depreciation of N407,250.00

The depreciation values of the above fixed costs will be used in the place of a mean total cost for each item.

\begin{tabular}{|c|c|c|c|c|c|c|c|}
\hline \multirow[t]{2}{*}{ Items } & \multirow{2}{*}{$\begin{array}{c}\text { Use } \\
\text { Life } \\
\text { (Years) }\end{array}$} & \multicolumn{3}{|c|}{ Mean Total Cost (Naira) } & \multicolumn{3}{|c|}{ Depreciation (Naira) } \\
\hline & & $\begin{array}{l}\text { Small } \\
\text { Scale }\end{array}$ & $\begin{array}{l}\text { Medium } \\
\text { Scale }\end{array}$ & Large scale & Small scale & $\begin{array}{l}\text { Medium } \\
\text { scale }\end{array}$ & $\begin{array}{l}\text { Large } \\
\text { scale }\end{array}$ \\
\hline $\begin{array}{c}\text { Buildings \& } \\
\text { Pens }\end{array}$ & 20 & $520,714.29$ & $2,014,705.88$ & $5,875,000$ & $26,035.71$ & $100,735.29$ & 293,750 \\
\hline Cages & 20 & $191,008.45$ & $964,500.00$ & $1,500,000$ & $9,550.42$ & $48,225.00$ & 75,000 \\
\hline Wheelbarrow & 2 & $5,945.61$ & $11,240.63$ & 21,000 & 2972.807018 & 5620.3125 & 10,500 \\
\hline Generator & 5 & $61,528.95$ & $103,617.65$ & 140,000 & $12,305.79$ & $20,723.53$ & 28,000 \\
\hline Other Items & 2 & $8,657.14$ & $30,066.67$ & & $4,328.57$ & $15,033.33$ & \\
\hline TOTAL & & $787,854.44$ & $312,430.83$ & $7,536,000.00$ & $55,193.29$ & $109,337.46$ & $407,250.00$ \\
\hline
\end{tabular}

Table 3: Depreciation Schedule

Source: field survey: 2017

\subsubsection{Profitability of Each Scale of Enterprise}

The result of profitability of the poultry-egg enterprise by stock sizes is presented in Table 2. It was found that over $98 \%$ of the cost of production was on account of variable inputs. It was revealed that cost of feed accounted for the bulk of the variable cost and as a matter of fact, the cost of production in general. This goes in line with the study of Sekoni (2000) and Umar (2012) that indicated that cost of feed is the largest single variable cost in animal production. The analysis showed that the small and medium scale poultry-egg farmers incurred more on feed $(83.80 \%$ and $85.18 \%$ respectively) than the large scale that incurred $76.41 \%$ of their total cost on feed. This can be due to the fact that the largescale enterprises enjoy the economies of scale; they are given discount due to bulk purchase or they produce their feed themselves at a lower cost. The large scale poultry farmers who produce their own feed are able to cut off the margin of the feed millers and the feed marketers, hence his lower feed cost. The very high percentage of cost of feed in all the scales is in line with cost structure for the poultry industry in general (Umar 2012). Followed by the cost of feed is the cost of stock. Among the small scale farmers, cost of stock was $11.57 \%$, for medium scale, it was $11.56 \%$ and $17.23 \%$ for large scale. The high proportion of cost of stock may be due to the fact that the farmers use the latest technology thereby limiting the number of labour needed. Comparing the total variable cost of each scale, it shows that the large enterprise incurred most variable cost followed by the medium scale and finally the small scale. The depreciation was calculated for each fixed costs and the result revealed that the highest cost was incurred on buildings and pens. Sales of eggs is the major source of revenue in the enterprise. The large scale enterprise had the least revenue from sales of egg when compared with the percentages of other scales and this could be due to the fact that they produce so many eggs and have to sell at cheaper rate as soon as possible to prevent spoilage. The spent layer also contributed to the total revenue of the enterprise. The small scale got $9.48 \%$ of its revenue from spent layers medium and large scale got $10.92 \%$ and $11.58 \%$ respectively. 


\begin{tabular}{|c|c|c|c|c|c|c|}
\hline Mean Cost Item & Small Scale & $\mathbf{\%}$ & Medium Scale & $\mathbf{\%}$ & Large Scale & $\mathbf{\%}$ \\
\hline Variable Cost & & & & & & \\
\hline Stock & $502,175.68$ & 11.57 & $2,130,000.00$ & 11.56 & $8,500,000.00$ & 17.23 \\
\hline Feed & $3,636,699.32$ & 83.80 & $15,700,000.00$ & 85.18 & $37,700,000.00$ & 76.41 \\
\hline Labour & $7,351.35$ & 0.17 & $15,400.00$ & 0.08 & $15,000.00$ & 0.03 \\
\hline Drugs and Vaccines & $43,805.34$ & 1.01 & $181,300.00$ & 0.98 & $1,175,000.00$ & 2.38 \\
\hline Utilities & $86,370.14$ & 1.99 & $189,994.00$ & 1.03 & $703,000.00$ & 1.42 \\
\hline Other Variable Cost & $8,388.89$ & 0.19 & $25,000.00$ & 0.14 & $840,000.00$ & 1.70 \\
\hline Total Variable Cost & $4,284,790.72$ & 98.73 & $18,241,694.00$ & 98.97 & $48,933,000.00$ & 99.17 \\
\hline Fixed Cost & & & & & & \\
\hline Buildings \& Pens & $26,035.71$ & 0.60 & $100,735.29$ & 0.55 & $293,750.00$ & 0.60 \\
\hline Cages & $9,550.42$ & 0.22 & $48,225.00$ & 0.26 & $75,000.00$ & 0.15 \\
\hline Wheelbarrow & $2,972.81$ & 0.07 & $5,620.31$ & 0.03 & $10,500.00$ & 0.02 \\
\hline Generator & $12,305.79$ & 0.28 & $20,723.53$ & 0.11 & $28,000.00$ & 0.06 \\
\hline Other Fixed Items & $4,328.57$ & 0.10 & $15,033.33$ & 0.08 & & 0.00 \\
\hline Total Fixed Cost & $55,193.30$ & 1.27 & $190,337.46$ & 1.03 & $407,250.00$ & 0.83 \\
\hline TOTAL COSTS & $4,339,984.02$ & 100 & $18,432,031.46$ & 100 & $49,340,250.00$ & 100 \\
\hline Revenue & & & & & & \\
\hline Eggs & $4,177,076.35$ & 90.52 & $18,600,000.00$ & 89.08 & $53,000,000.00$ & 88.42 \\
\hline Spent Layers & $437,397.30$ & 9.48 & $2,280,000.00$ & 10.92 & $6,940,000.00$ & 11.58 \\
\hline TOTAL REVENUE & $4,614,473.65$ & 100 & $20,880,000.00$ & 100 & $59,940,000.00$ & 100 \\
\hline NET FARM INCOME & $274,489.63$ & & $2,447,968.54$ & & $10,599,750.00$ & \\
\hline
\end{tabular}

Table 4: Cost and Returns of Poultry Egg Farmers

The high proportion of the cost of stock may is also in line with evidences from literature (Umar 2012). Cost of labour is highest in the small-scale enterprise followed by the medium scale while the large scale has the least cost of labour, this could be due to the fact that large scale farmers use the latest technology thereby limiting the number of labour needed. Comparing the percentage for total variable cost of each scale, it shows that the large scale enterprise incurred the most variable cost, followed by the medium scale enterprise and finally the small scale enterprise. The depreciation was calculated for each fixed costs and the result revealed that the most cost was incurred on buildings and pens. Sales of eggs in small scale enterprise provided about $90.52 \%$ of the revenue while it provided $89.08 \%$ and $88.42 \%$ revenue in the medium and large scale enterprise respectively. This indicates that sales of eggs are the major source of revenue in the enterprise. The large scale enterprise had the least percentage of revenue from sales of eggs when compared with the other scales and this could be due to the fact that they produce so many eggs and had to sell at cheaper rate as soon as possible to wholesalers, distributor or manufacturers that uses eggs as raw material so as to prevent spoilage. The small scale farmers can however retail theirs and hence obtain higher profit. The spent layers also contributed to the total revenue of the enterprise. The small scale enterprise got $9.48 \%$ of its revenue from spent layers, medium and large scale got $10.92 \%$ and $11.58 \%$ respectively. Thus, for the small scale farmers, the net farm income was $\mathrm{N} 274,489.63$, the medium scale farmers had a net farm income of $\mathrm{N} 2,447,968.54$ while the large scale enterprise had the a net farm income of $\mathrm{N} 10,599,750.00$.

\subsection{Estimation of Technical, Economic and Allocative Efficiencies}

\subsubsection{Technical Efficiency Analysis}

The technical efficiency shows the ability of farmers to derive maximum egg production from the inputs available to them. The result of the Technical Efficiency is presented in Table 12 . About $4.4 \%$ of the farmers were operating under $60 \%$ efficiency while majority, which is $40.9 \%$ of them achieved $90 \%$ to $97 \%$ technical efficiencies. From $20 \%$ to $25.2 \%$ of the farmers fell within the 0.70-0.79 and 0.80-0.89 efficiency ranges, respectively. The mean technical efficiency of the farmers in the study area was $83.1 \%$ which means that on the average, the respondents were able to obtain just over $83.1 \%$ of optimal output from a given set of inputs while the minimum and maximum efficiencies were $13 \%$ and $97 \%$, respectively. Thus, if least efficient farmer in the study area was to attain the technical efficiency level of the most efficient farmer, then farmer could realize $87.63 \%$ cost saving [i.e., 1-(0.13/0.97) x100]. Essentially, about $86.6 \%$ of the farmers are at least $70 \%$ efficient in their egg production while if an average farmer was to attain the technical efficiency level of the most efficient farmer, then the average farmers would realize $14.33 \%$ cost saving [i.e., $1-(0.831 / 0.97) \times 100$ ] 


\begin{tabular}{|c|c|c|}
\hline Range & Frequency & Percentage \\
\hline$<0.20$ & 1 & 0.9 \\
\hline $0.20-0.29$ & 0 & 0.0 \\
\hline $0.30-0.39$ & 0 & 0.0 \\
\hline $0.40-0.49$ & 1 & 0.9 \\
\hline $0.50-0.59$ & 3 & 2.6 \\
\hline $0.60-0.69$ & 11 & 9.6 \\
\hline $0.70-0.79$ & 23 & 20.0 \\
\hline $0.80-0.89$ & 29 & 25.2 \\
\hline $0.90-0.97$ & 47 & 40.9 \\
\hline $\begin{array}{ll}\text { Total } & \\
\text { Mean } & 0.831 \\
\text { Std. Deviation } & 0.129 \\
\text { Minimum } & 0.13 \\
\text { Maximum } & 0.97 \\
\end{array}$ & 115 & 100.0 \\
\hline
\end{tabular}

Table 5: Distribution of Technical Efficiency among Poultry Egg Farmers

Source: field survey; 2017

\subsubsection{Economic Efficiency Analysis}

The economic efficiency analysis of the poultry egg producers is presented in Table 13 . The estimate revealed that there was presence of cost inefficiency effects in egg production as confirmed by the significance of the gamma value of 0.750 at $5 \%$ level of probability. This implies that about $75 \%$ variation in the total production cost is due to differences in their cost efficiencies. About 3.5\% of the farmers were below $50 \%$ economic efficiency while about $43.5 \%$ of the farmers were within $0.80-0.89$ economic efficiency range. The estimated economic efficiencies estimated as the inverse of cost efficiencies was different from farmer to farmer ranging between 0.26 and 0.95 with a mean of 0.771 . This implies that if an average farmer was to attain the economic efficiency level of the most efficient farmer, then the average farmer would realize $18.84 \%$ in cost saving [i.e., 1-(0.771/0.95)x100]. However, for the least economically efficient farmer to attain the level of the most efficient farmer, about $72.63 \%$ would be saved in terms of cost.

\begin{tabular}{|c|c|c|}
\hline Range & Frequency & Percentage \\
\hline$<0.20$ & 0 & 0.0 \\
\hline $0.20-0.29$ & 1 & 0.9 \\
\hline $0.30-0.39$ & 0 & 0.0 \\
\hline $0.40-0.49$ & 3 & 2.6 \\
\hline $0.50-0.59$ & 4 & 3.5 \\
\hline $0.60-0.69$ & 12 & 10.4 \\
\hline $0.70-0.79$ & 40 & 34.8 \\
\hline $0.80-0.89$ & 50 & 43.5 \\
\hline $0.90-0.99$ & 5 & 4.3 \\
\hline $\begin{array}{lc}\text { Total } & \\
\text { Mean } & 0.771 \\
\text { Std. Deviation } & 0.106 \\
\text { Minimum } & 0.26 \\
\text { Maximum } & 0.95\end{array}$ & 115 & 100.0 \\
\hline
\end{tabular}

Table 6: Distribution of Respondents Based on Economic Efficiency

Source: field survey: 2017

\subsubsection{Allocative Efficiency (AE) Analysis}

Allocative efficiency was estimated to obtain an overview of how well the farmers were able to select and combine input resources available to them given market constraints to produce poultry eggs. The result is presented in Table 14 . The estimation revealed that the farmers were at least $50 \%$ efficient in selecting and combining their inputs to achieve their productivity. While $3.5 \%$ operated on the frontier line with their AE being 1.00 , where $34.8 \%$ of the farmers had AE between 0.90 and 0.99 which is very close to 1.00 . The mean $\mathrm{AE}$ was 0.948 . The least efficient was 0.57 and the most efficient was 1.00 and those beyond the frontier line were $25.2 \%$. Thus, if the least farmer in the sample was to achieve AE level of its most efficient counterpart, then the average farmer could realize $43 \%$ cost saving [i.e., $1-(0.57 / 1.00)$ x100]. 


\begin{tabular}{|c|c|c|}
\hline Range & Frequency & Percentage \\
\hline $0.50-0.59$ & 1 & 0.9 \\
\hline $0.60-0.69$ & 4 & 3.5 \\
\hline $0.70-0.79$ & 8 & 7.0 \\
\hline $0.80-0.89$ & 29 & 25.2 \\
\hline $\begin{array}{c}0.90-0.99 \\
1.00 \\
>1.00\end{array}$ & $\begin{array}{c}40 \\
4 \\
29\end{array}$ & $\begin{array}{c}34.8 \\
3.5 \\
25.2\end{array}$ \\
\hline $\begin{array}{lc}\text { Total } & \\
\text { Mean } & 0.948 \\
\text { Std. Deviation } & 0.173 \\
\text { Minimum } & 0.57 \\
\text { Maximum } & 2.11 \\
\end{array}$ & 115 & 100.0 \\
\hline
\end{tabular}

Table 7: Distribution of Respondents Based on Allocative Efficiency

Source: Field Survey; 2017

If $A \cdot E=1$ then the input is optimally/efficiently used and if $A \cdot E<$ or $>1$ then input is inefficiently used

\subsubsection{Estimates of the Stochastic Production Function and Inefficiency Parameters of Poultry Egg Farms}

From the results, feed consumed and the size of stock were the inputs that had significance influence on egg production in the study area. Both of them were significant at $1 \%$ while drugs and labour were found not to be significant. The use of labour by the farmers was negatively related to egg production. Thus, the more the labour used in the production process, the lower the productivity. This may be as a result of the scale of production in the study area. Thus, increasing labour in the production process that is largely small scale will increase the cost of production without substantial increase in egg production. The positive relationship of the feed consumption with egg production indicated that as feed consumption increases, egg productivity increases. The Stock size and drugs administered on the birds also had positive relationship with egg production which implies that the higher they are, the more eggs are produced. The inputs used in the production process had the expected signs. Concerning the signs of the coefficient of inefficiency variables, they are important in explaining the level of observed technical inefficiency among poultry egg producers. A negative sign implies that the variable has the effect of reducing technical inefficiency whilst a positive sign has the effect of increasing it. From the result, feed consumed and size of stock are the inputs that significantly influence egg production in the study area.

The gamma $(\gamma)$ value of 0.986 which is statistically significant at $1 \%$ indicated that about $99 \%$ of the residual variation in egg production was due to inefficiency effect. While gender, family size, educational level and farming experience followed a priori expectation in their signs, age, membership of cooperative, access to credit, and marital status did not follow a priori expectation in their signs. However, none of the identified socioeconomic variables had significant influence on egg production. This means the null hypothesis that Socio-economic characteristics of poultry egg farmers do not significantly affect their technical efficiency can be accepted. It can be said that all the variables in the model did not contribute to technical inefficiency among the poultry farmers. The level of technology that was however not included may be an important determinant of inefficiency.

\begin{tabular}{|c|c|c|c|}
\hline $\begin{array}{l}\text { Variable } \\
\text { ratio }\end{array}$ & Coefficient & Std. Error & t- \\
\hline \multicolumn{4}{|l|}{ General Model } \\
\hline Constant & 1.932 & 0.231 & \\
\hline \multicolumn{4}{|l|}{$8.382^{* * *}$} \\
\hline Feed & 0.148 & 0.049 & $3.026 * * *$ \\
\hline Labour & -0.062 & 0.036 & -1.714 \\
\hline Drugs & 0.011 & 0.007 & 1.607 \\
\hline Stock Size & 0.887 & 0.049 & $18.192 * * *$ \\
\hline \multicolumn{4}{|l|}{ Inefficiency Model } \\
\hline Age & 0.064 & 0.148 & 0.435 \\
\hline Educational Level & 0.282 & 0.647 & 0.435 \\
\hline Farming Experience & -0.381 & 0.307 & -1.238 \\
\hline Membership of Cooperative & 0.840 & 0.519 & 1.619 \\
\hline Access to Credit & -0.782 & 0.716 & -1.093 \\
\hline Gender & -0.656 & 0.668 & -0.982 \\
\hline Marital Status & -3.072 & 1.885 & -1.630 \\
\hline Household Size & -0.872 & 0.602 & -1.449 \\
\hline Sigma-squared & 0.515 & 0.233 & $2.214^{* *}$ \\
\hline Gamma & 0.986 & 0.008 & \\
\hline $20.885^{* * * *}$ & & & \\
\hline
\end{tabular}




\subsubsection{Constraint to Poultry-Egg production}

The result in Table 16 shows the distribution of respondents according to the constraints they are facing. Respondents rated high cost of input as the major constraint. Anwasia (2015) also reported that high cost of input such as feed is the major constraint in the industry. High cost of inputs make it difficult for existing enterprise to expand the scale of their production thereby causing stagnation and or low returns. About $15.9 \%$ of the respondents stated that there is inadequate market for the outputs or market glut. Glut thereby will cause fall in price which will reduce the returns. Availability of fund is another constraint being faced by the respondents. About $15.6 \%$ of the respondents stated that lack of fund is a problem in their various enterprise. This can be due to the high interest rates or collateral requested by the sources and this could be the reason farmers could not afford to get credits to acquire necessary inputs or expand their enterprises at will. Pests and diseases is also a constraint facing the enterprise and this could be the cause of inefficiency in the enterprise because the mortality rate will be high and also productivity will be reduced. $12.6 \%$ of the respondents stated that transportation is a problem in their enterprises this is because of the poor road network causing some of the eggs to break on the way to the market. The respondents pointed storage facilities as the least important problem to their business. The eggs can only be stored for few days and must be disposed even when the price is not favourable in order to avoid total loss.

\begin{tabular}{|c|c|c|}
\hline Constraints & Frequency & Percentage \\
\hline Pest and diseases outbreak & 50 & 43.48 \\
\hline High cost of inputs & 103 & 89.57 \\
\hline Inadequate storage facilities & 33 & 28.70 \\
\hline Transportation & 42 & 36.52 \\
\hline Lack of funds & 52 & 45.22 \\
\hline Lack of market & 53 & 46.09 \\
\hline Total & $333^{*}$ & \\
\hline
\end{tabular}

Table 9: Distribution of Respondents According to Constraints they faced *Multiple Responses

Source: field survey; 2017

\section{Conclusion}

Feed was the highest variable cost item with small and medium enterprises recording $83.80 \%$ and $85.18 \%$ respectively. The large scale farmers had $76.41 \%$ of their total cost accounted for by feed. Sales of eggs and spent layers were the sources of income in the enterprise. Sales of eggs in small scale enterprise provided about $90.52 \%$ of the revenue while it provided $89.08 \%$ and $88.42 \%$ revenue in the medium and large scale enterprise, respectively.

The result of the technical efficiency of the farmers shows that $4.4 \%$ of the farmers were operating below $60 \%$ efficiency while majority which is $40.9 \%$ of the farmers were also most efficient in maximizing their egg production. $20 \%$ and $25.2 \%$ of the farmers fell within the 0.7-0.79 and 0.8-0.89 efficiency respectively. The mean technical efficiency of the farmers in the study area was $83.1 \%$ while the minimum and maximum technical efficiencies were $13 \%$ and $97 \%$ respectively.

The economic efficiency analysis revealed that there was cost inefficiency effects in egg production. There was $75 \%$ variation in the total production cost and this is due to the differences in their cost efficiencies. It also shows that about $3.5 \%$ of the respondents were below $50 \%$ economic efficiency while more of the farmers about $44 \%$ of the farmers were within 0.80-0.89 economic efficiency range.

The allocative efficiency analysis shows that the farmers were at least $50 \%$ efficient in selecting and combining in selecting and combining their inputs to achieve their productivity. 3.5\% operated on the frontier line with their allocative efficiency being 1.00 . $34.8 \%$ of the farmers had allocative efficiency between 0.90 and 0.99 which is close to 1.00 . The mean allocative efficiency was 0.948 .

The factors affecting the technical efficiency were also analyzed and the result showed that the socio-economic characteristics influenced the farmers' technical efficiency, there are no socio-economic characteristics that significantly influenced farmers' productivity.

It can therefore be concluded that, majority of the poultry-egg farmers in the study area were operating on a small- scale and all the scales of production were profitable.

The mean technical efficiency of the farmers in the study area was $83.1 \%$ while the minimum and maximum efficiencies were $13 \%$ and $97 \%$. This indicates that opportunities still exists for increased productivity and income of poultry-egg farmers. The level of efficiency among the poultry enterprise can be increased by $16.9 \%$ through a better use of resources available, given technology and addressing the constraints to the enterprise. The result also showed that none of the identified socio-economic variables had significant influence on the production of egg. High cost of inputs was the highest constraint in the study area followed by inadequate of market for the and inadequate of funds.

\subsection{Recommendations}

Based on the conclusion, it can therefore be recommended that, funds should be made available to the farmer by providing macro-credits to the farmers because inadequate funding was the highest constraint identified by the farmers. Also, policies and programmes that will make macro-credits from appropriate agencies accessible should be made by the regulatory bodies. Programmes that will encourage and facilitate economic production of poultry feed ingredients like maize, wheat, soya-beans should be instituted for least cost production of the feed. 
Farmers should practice good hygiene so as to reduce the outbreak of pest and diseases to the minimum. Farmers should be enlightened on how to sufficiently administer drugs and vaccine to the birds.

Importers and manufacturers of poultry equipment should be given subsidy and credit respectively to reduce their importation and production cost. A platform whereby farmers, wholesalers, retailers and consumers can meet and transact business should be made.

\section{References}

i. Aboki E, Jongur A.A.U, Onu J.I. Productivity and Technical Efficiency of Family Poultry Production in Kurmi Local Government Area of Taraba State, Nigeria.

ii. Adamu H. M (2010) Major antinutrients found in plant protein. Pakistan Journal of Nutrition vol. 9,8: pg 827-832.

iii. Adebayo, 0.0. and R.G. Adeola. 2005. Socio- economics factors affecting poultry farmers in Ejigbo local government area of Osun State.J. Hum. Ecol., 18: 39-41.

iv. Adepoju, A. A. (2008).Technical efficiency of Egg Production in Osun state, International journal of Agricultural Economics and Rural Development: (1) pg. 7-14.

v. Adesina A.A., Djato K.K. (1997).Relative Efficiency of Women as Farm Managers:

vi. Profit Function Analysis in Cote divoire, Journal of Agric. Economics. 16: pg 47-53. Agricultural Transformation Agenda (2012). Federal Government of Nigeria.

vii. http://www.emrc.be/documents/document/20121205120841-agri2012-special_session-tony_bellomin_agric_nigeria.pdf.

viii. Afolabi O.I, Adegbite D.A, Ashaolu O.F, Akinbode S.O (2013). Profitability and resource-use efficiency in poultry egg farming in Ogun State, Nigeria. African Journal of Business management Vol. 7(16), pg. 1536-1540.

ix. Ajibade, L.T., P.O. Fatoba, U.A. Raheem and B.A. Odunuga (2005).Ethnomedicine and

X. Primary Healthcare in Ilorin, Nigeria, Indian Journal of Traditional Knowledge. Vol. 4(2) pg 150-158.

xi. Ajibefun, I.A and A.O. Abdulkadiri (1999).An Investigation of Technical Inefficiency of Production of Farmers under the National Directorate of Employment in Ondo State, Nigeria, Applied economics letter. 6: pg 111-114.

xii. Ajibefun, I.A., G.E. Battese and A.G. Daramola (2002).Determinants of Technical efficiency in Small Holder Food Crop Farming: Application of Stochastic Frontier Production function. Journal of international Agriculture. 41: pg 225-240.

xiii. Ajibefun, I.A. (2006). Linking Socio-economic and Policy Variables to Technical

xiv. Efficiency of Traditional Agricultural Production: Empirical Evidence from Nigeria. Poster paper prepared for presentation at the International Association of Agricultural Economists Conference, Gold Coast, Australia, August pg. 12-18.

xv. Akinwumi, J.A., J.A., Adegeye, A.E. Ikpi and S.O. Olayide (1979).Economic Analysis of Nigeria Poultry Industries: A report submitted to the federal livestock Department, Lagos. Pg 49-78.

xvi. Akpabio, I. A, Okon, D. P, Angba, A. O. and Aboh, C. L. 2007. Avian Influenza Scare and Poultry egg Production in Uyo urban, Nigeria. International Journal of Poultry Sciences, 6(4): pg 298-301.

xvii. Alabi, R.A. and M.B. Aruna (2006). Technical Efficiency of Family Poultry Production Niger Delta, Nigeria, Journal Central European Agriculture 6(4) pg 531-538.

xviii. Alexander, D.J. (1991). Newcastle disease In Rweyemamu, M.M., Palya, V., WIN, T. \& Sylla. D., eds. Newcastle disease vaccines for rural Africa. Proceedings of a Workshop held at the Pan African Veterinary Vaccine Center (PANVAC), Debre Zeit, Addis Ababa, Ethiopia, 22-26 April 1991, Pg 7-45.

xix. Ali, M.D. (2002).Nigeria poultry and products-poultry update. USDA, Foreign Agriculture service: GAIN report N12025.

xx. Amar-Klemesu, M. and Maxwell, D. (2000). Accra: Urban Agriculture as an asset Strategy. In: Supplementary Income and Diets, Bakker, N., Dubbeling, M., Gundel, S., Koschella, U.S. and dezeeuw, H. (Eds.). Growing Cities, Growing Food, Havana, Cuba, pg 234-236.

xxi. Amata, P.S. \& Olayemi, J.K. (1998). An Investigation of Production Efficiency in Food Crop Enterprises, Gombe State, Nigeria. Journal of Rural Economics and Development. Vol.13, 1998/1999 pp. 111-122.

xxii. Amos, T. T. 2006. An analysis of backyard poultry production in Ondo State, Nigeria. International Journal of poultry science, 5(3): pg $247-250$.

xxiii. Anwasia A. I 2015. Production Efficiency of Small-Scale Broiler Farmers in Delta State, Nigeria. A Dissertation submitted to the department of Economics University of Nigeria Nnsuka.

xxiv. Anyanwu S.0, Ezedinma C.I. Comparative Analysis of Technical Efficiencies between compound and noncompound farms in Imo State, Nigeria. Journal of Agricultural and social Research. 2006; 6(2): pg 73-79.

xxv. Ashagidigbi, W.M, S.A. Sulaiman and A. Adesiyan (2011).Technical and Allocative

xxvi. Efficiency of Poultry Egg Producers in Nigeria, Madwell Agricultural Journal Vol. 6(4): pg 124- 130.

xxvii. Bamiro M. O (2008) Economic performance of commercial poultry farms in Oyo state Nigeria. International Journal of Poultry science, 7(11):pg 1117-1121.

xxviii. Battese, G.E. \& T.J. Coelli (1995). “A Model for Technical Inefficiency Effect in

xxix. Stochastic Frontier Production Functions for Panel Data”. Empirical Economics, 20: pg 325-332.

xxx. Baumol, W.J. (1977). Economic theory and operation analysis, New Jersey, prentice-hall, Englewood, Cliffs. Beutler, A. (2007). Introduction to Poultry Production in Saskatchewan, University of SaskatchewanS7N5A8

xxxi. Binuomote, S.0, J.0. Ajetomobi and A.0. Ajao (2008).Technical Efficiency of Poultry Egg Producers in Oyo State of Nigeria, International journal of poultry science 7(12): pg 1227-1231. 
xxxii. Chabeuf, N. (1990). Disease Prevention in Small Holder Village Poultry Production in Africa. In Proceedings, CTA Seminar on Small Holder Rural Poultry Production. Thessaloniki, Greece, 9-13 October 1990, Vol. 1, pg 129-137.

xxxiii. Coelli, T.J. (1996). A Guide to FRONTIER 4.1: "A Computer Programme for Stochastic Frontier Production and Cost Function Estimation". Working Paper in Center for Efficiency and Productivity Analysis. Department of Econometrics, University of New England, Armidale. Pg 32-36.

xxxiv. Coelli, T.J., Battese, G. (1996) Identification of Factors which influence farmers. Australian Journal of Agricultural Economics, 40:pg 103-128

xxxv. Copland, J.W. (1987). Newcastle disease in Poultry. A new food pellet Vaccine. ACIAR Monograph No.5. Canberra, Australia, ACIAR.

xxxvi. Dovel, G.H., (1996). Time- lag Phenomenon in Record keeping: Resistance or Inappropriateness. Journal of Extension Systems. 12(2) pg 16-32.

xxxvii. Effiong, E.0. (2005). Efficiency of Production in Selected Livestock Enterprises in Akwa Ibom State, Nigeria. A PhD Dissertation Submitted to the Department of

xxxviii. Agricultural Economics, Michael Okpara University of Agriculture, Umudike. Effiong, E.O. and Onyenweaku. C.E. (2006). Profit Efficiency in Broiler Production in Akwa Ibom State. International Journal of Agriculture and Development 7(1)

xxxix. Elson, H. A. (2011) Housing and husbandry of laying hens. Past Present and Future. Lohmann Information, 46, pg. 16-24.

xl. Eruvbetine, D. Aiyedum, M.D. \& Kusumo, B.C., (1999). The Effect of Cassava-Soya Inclusion in Diet for Broiler Chicken. Book of proceeding NSAP 26th Annual Conference. Pg 105-109

xli. Ezeh, C. I, Anyiro, C. 0, and Chukwu, J. A. 2012. The Technical Efficiency of Broiler

xlii. Production in Umuahia Capital Territory of Abia State Nigeria.Greener Journal of Agricultural Science 2(1), pg 001007

xliii. Farran M., (2006) Life Cycle Cost for rehabilitation of Public Infrastructure; application Farrell, M.J. (1957).Measurement of Productive Efficiency, Journal of Royal statistical Society Series, 3: pg 253-290.

xliv. Feder, G.S., Just., R.E. \& Zilberman. D. (1985). “Adoption of Agricultural Innovation in Developing Countries: A Survey". Economic Development and Cultural Changes, 33, pg 355-398.

xlv. Folorunsho O. R and Onibi, G. E. 2005. Assessment of Nutritional quality of Eviscerated waste from selected chicken type. In: Onibi G. E, Agele, S. O. and Adekunle V. A. J. (eds) (2005). Proceeding of the 1st Annual Conference on Development in Agricultural Technology. Federal University of Technology Akure, Nigeria Pg $300-303$. Food and Agricultural Organisation of the United Nations (FA0), (2003). A guide to seaweed industry. Rome, Italy.pg 87

xlvi. Food and Agricultural Organisation of the United Nations (FA0), (2010). Poultry Meat and Eggs: Agribusiness Handbook. Director of Investment Centre Division, FAO., Rome, Italy, pp: 77.

xlvii. Food and Agricultural Organisation of the United Nations [FA0], (2006). Poultry review-Ghana: The structure and importance of the commercial and village based poultry in Ghana, by K.G. Aning. Final review report. Rome.

xlviii. Food and Agricultural Organization of the United Nations; statistics Division (FA0STAT) (2014) Production: Livestock Primary" Eggs Primary.

xlix. Gerzilov, V., Datkova, V., Mihaylova, S. and Bozakova, N, (2012) Effect of Poultry Housing Systems on Egg Production. Bulgarian Journal of Agricultural Science, 18, pg 953-957.

1. Gona, A. 2009. Production Efficiency Among selected Livestock Fattening Enterprise in

li. Kebbi State, Nigeria. A Stochastic Frontier Production Function approach. Unpublished PhD Theses, Usman Danfodio University, Sokoto.

lii. Greene, W.H (1993). The Econometrics Approach to Efficiency Analysis" in Fried;

liii. Haddad, Lawrence, John Hoddinott, and Harold Alderman, eds. 1997. "Intrahousehold Resource Allocation in Developing Countries: Methods, Models and Policy. Baltimore: Johns Hopkins University Press for the International Food Policy Research Institute.

liv. Hassan, A. H. et al (2002). Function and selectivity of bromodomains in anchoring chromatin-modifying complexes to promote nucleosomes. Cell 111(3); pg 69-79.

lv. Heady, E.O. (1960). Economic of Agricultural Production and Resource-use, Prentice-hall New Jersey.

lvi. Huchzermeyer, F.W. (1993). Why is Velogenic Newcastle Disease Endemic in some

lvii. Countries and not in others? Zimbabwe Veterinary Journal, 24(3), pg 111-113. Ikeme, A.I, (1990). The Challenges of Agriculture in National Development. Enugu

lviii. Optimal Publisher. Pg. 296-303.

lix. Jatto N.A, Maikasuwa M.A, Jabo M.S.M, Gunu U.I. Assessing the technical efficiency of level of Poultry Egg producers in Kwara State. European Scientific Journal, Nov. edition vol. 8, No. 27. ISSN. Pg 1857-7881.

lx. Juliet Roberts, R. (2004). Factors affecting internal quality and egg shell quality in laying hens. Journal of Poultry Science, 41:pg 161-177.

lxi. Kekeocha, C.C, (1984). Poultry Production Handbook. Nairobi, Pfizer Corporation. Pg. 92- 110. Lewis, G.D and Lovell, C.A.K. (1990). Technical Efficiency Estimates. Journal of Agricultural Economics, 20 (2), pg 60-67.

lxii. Lipsey, G. R. (1983), An introduction to positive economics ELBS/Weindenfeld and Nicolson, Inland pg 231.

lxiii. Mbanasor, J.A. (2002): "Resource use pattern among poultry enterprises in Abia State Nigeria". Nigeria Journal of Animal Production. 29: pg 64- 70. 
lxiv. Mbanasor, J.A and Kalu, K.C. (2008). “Economic Efficiency of Commercial Vegetable

lxv. Production System in Akwa Ibom State, Nigeria: A Translog Stochastic Cost Function Approach". Tropical and Subtropical Agrosystems 8(3): pg. 313-318.

lxvi. National Bureau of Statistics (NBS) official website http://www.nigerianstat.gov.ng.

lxvii. Ngoka, D.A, Froning G.W and Babji A.S. (1983). Effect of temperature on egg yolk characteristics of egg from young and old laying hens. Poult Sci. 62(4): pg718-720.

lxviii. Nurudeen, AJ (2012). Economics and social characteristics of registered poultry egg producers in Ilorin, Kwara state. Russian J. Agric. SocioEcon. Sci. 11:11.

lxix. Nwaru, J.C. (2003). "Gender and Relative Production Efficiency in Food Crop Farming in Abia State of Nigeria". Nigerian Agricultural Journal 34:1-10.0bioha, F.C. (1992). A Guide to Commercial Poultry Production in the Tropics. Enugu, Acena Publishers. Pp. 26-30.

lxx. Ohajianya D.O, Onu P.N Ugwu J.N, Osuji M.N, Nwaiwu U.I, Orebiyi J.S, Godson-Ibeji C.C and Enyia C.O. Technical efficiency of table egg Producers in Imo state, Nigeria. Asian Journal of Agricultural Extension, Economics and Sociology. 2(2): pg118-127, 2013. AJAEES.2013.002.

lxxi. Ocholi, R. A, Oyetunde, I.I, Kumblish P., Odugbo M. O \& Taama et al, (2006). Epidemiology of an outbreak of highly pathogenic avian influenza caused by the virus subtype H5N1 in Nigeria in 2006. VOM J. Vet. Res.inst. Jos, pp;1-18.

lxxii. Ojo S. O (2003). Productivity and Technical Efficiency of Poultry Egg Production in Nigeria. International Journal of Poultry. Science. 2(6): pg 459-464.

lxxiii. Okonkwo, W.I and Akubuo C.O (2001) Thermal Analysis and Evaluation of heat requirement of a passive solar energy poultry chick brooder in Nigeria. Journal of renewal Energy 9 (1) pg37-39. Okoli, I. C. 2006. Technical note on animal management and health issues, Tapas

lxxiv. Institute. Department of Animal Science. Federal University of Technology Owerri, Nigeria.

lxxv. Olabode, A.O., Lamorde, A.G., Shiidali, N.N., Chukweudo, A.A. and Spradbrow, P.B.

lxxvi. (1992). Village chickens and Newcastle disease in Nigeria. In Spradbrow, P.D., ed.Newcastle disease in village chichens: Control with Thermostable Oral Vaccines. ACIAR Proceedings, No. 39. Canberra, Australia, ACIAR. Pg. 159160.

lxxvii. Oladeebo J.O. Ambe-Lamidi A.I. Profitability, Input Elasticities and Economic Efficiency of Poultry Production Among Youth Farmrs in Osun State, Nigeria. International Journal of Poultry Science. 6(12): pg994-998.

lxxviii. Olawumi S. O, Adeoti I. A. (2009) Comparative economic analysis of black and brown commercial layer strains in Nigeria. International Journal of Poultry Science. 8(10): pg 1011-1013.

lxxix. Ologbon, O.A.C. and O.I. Ambali, 2012. Poultry Enterprise Combination among small-scale farmers in Ogun State, Nigeria: A technical approach. Journal of Agricultural Veterinary Science., pg 4:7-15.

lxxx. Olukosi JO, Ogungbile AO (1989). Introduction to agricultural production economics: Principles and application. AGITAB Publishers Ltd 1989.

lxxxi. Olukosi, J.0 and Erhabor P.0 1988 'Introduction to farms Management Economic; Principals and Applications.' Agitab Publishers Ltd Zaria Nigeria. Pp1-92

lxxxii. Omeke, B.C.O (1988) improving goat productivity in the humid zone of the tropics. Bulletin of Animal Health and Production in Africa 36(2): 126-130.

lxxxiii. Onyenweaku, C.E and E.O. Effiong (2006).Technical Efficiency in Pig Production in

lxxxiv. Akwalbom State, Nigeria, Paper Presented at the 40th Annual Conference of the Agricultural Society of Nigeria, held at NRCRI, Umudike.

lxxxv. Otunaiya A.O, Adeyonu A.G, Bamiro O.M. (2015) Technical Efficiency of Poultry Egg Production in Ibadan Metropolis, Oyo State, Nigeria. Economics (http://www.sciencepublishinggroup.com/j/eco). 4(3): pp50-56. doi: 10.11648/jeco20150403.12

lxxxvi. Oyenuga, V.A., (1996). The Level of the Nigeria Livestock Industry. World review of Animal Production. (1): pg 57.

lxxxvii. Oyedipe E.O. (2000).Optimizing the Potential of Livestock Production in Nigeria:

lxxxviii. Improving Nutritional Standard. Agric. Vet. int. 1 (2) pg 19-20.

lxxxix. Pandey, V.S. (1993), Epidermiology and Economics of Village Poultry Production in Africa: Overview. In Pandey, V.S. \&Demey. F., eds. Village Poultry Production in Africa, Proceedings of an International Workshop. 124-128.

xc. Russell, N.P. and T. Young (1983).Frontier Production Functions and the Measurement of Technical Efficiency. J. Agr. Econ. 34: 139-50.

xci. Rweyemamu, M.M., Palya, V., Win, T. \& Sylla, D. (1991). Newcastle Disease Vaccines for Rural Africa. Proceedings of a Workshop held at the Pan African Veterinary Vaccine Center (PANVVC), Debre Zeit, Addis Ababa, Ethiopia, 22-26 April 1991.

xcii. Saleh, S.A. (1995). Economic Analysis of Stock and Poultry Feed Resource in Egypt. Journal of Agricultural Science. 26 (1): 225-273.

xciii. Sean, P. \& Ines, H. (2002). Estimation of Technical Efficiency: A Review of some of Stochastic Frontier and DEA software. Virtual Edition Volb, Issue1.

xciv. Seiford, L.M. \& Thrall, R.M. (1990). Recent Development in DEA: The Mathematical

xcv. Programming Approach to Frontier Analysis, Journal of Econometics, 46, pg. 7-38. Sekoni, A. A. (2002). Poultry production in Nigeria: a training manual on national training workshop. NAPRI, ABU, Nigeria. 88-94.

xcvi. Sherwin, C. M., Richards, G.J. and Nicol, C.J. (2010). A comparison of welfare of layers in Four Housing Systems in the UK. British Poultry Science, 51, pg 488-499 
xcvii. Sonaiya E. B (1995). Feed resources for smallholder poultry in Nigeria. World Animal Review, 82(1): pg 25-33

xcviii. Sonaiya, E.B. (2000). Backyard poultry production for socio-economic Advancement of the Nigeria Family: Requirement for Research and Development. Nigerian Poultry Science Journal 1: pg 88-107.

xcix. Sonaiya, E.B. (2001). Small poultry holdings, the family and community developmentethology, ethics and selfinterest, Livestock Community and Environment. Proceedings of the 10th Conference of the Association of Institutions for Tropical Veterinary Medicine, Copenhagen, Denmark, 2001. Sparks, N. H. C. 2006. The Hens Egg. Is its role in human changes? Worlds Poultry Science Journal.

c. Spradbrow, P.B. \& Samuel, J.L. (1991). Oral Newcastle disease Vaccination with V4 virus in chickens: Comparison with other routes. Australian Veterinary Journal, 68 (3): pg 114-115.

ci. Tijjani H, Tijani BA, Tijjani AN, Sadiq MA (2012). Economic analysis of poultry egg production in Maiduguri and environs of Borno State, Nigeria. Journal of Agricultural science 2(12): pg 319-324.

cii. Tona, G.O. (1995). Incidence of worms in chickens on farms in Ikorodu Local Government Area of Lagos State, Nigeria. African Network of Rural Poultry Development Newsletter, 5 (1).

ciii. Ukoha, O. 0 and Agustine A. C. 2007. Technical Efficiency of Small Scale Poultry Egg

civ. Production in Nigeria. Empirical Study of Poultry Farmers in Imo State, Nigeria. Research Journal of Poultry Science, 1(3-4):16-21.

cv. Umar, M 2012. Economic Analysis of Poultry Egg Production in Bauchi State, Nigeria. A thesis submitted to the school of post graduate studies Ahmadu Bello University Zaria.

cvi. United States Department of Agriculture (USDA), (2013). International egg and poultry review. February 7, 1 6:8. Yao, S. and Liu, Z. (1998). Determinants of Grains Production and Technical Efficiency in China. Agricultural Economics 49(2):171-184.

cvii. Yusuf SA, Malomo 0 (2007). Technical Efficiency of Poultry Egg Production in Ogun State: A Data Envelopment Analysis (DEA) approach. Int. J. Poult. Sci. 6(9): pg 627-629.

cviii. Yusuf T.M (2011). Productivity and Resource Use Efficiency of Women Food Crops Farmers in the Derived Savannah Zone of Nigeria. Unpublished PhD

cix. Thesis. Department of Agricultural Economics University of Ibadan, Nigeria.

cx. Zahraddeen, D. I, Butswat, S.R., Sanusi, M. and Adamu, S.A. (2010) characterization of poultry farming in Nigeria; A case study of Taraba state. Cont. J Anim. Vet. Res., 2; pg 